\title{
The Repeal of the Affordable Care Act and Its Likely Impact on Chronic Pain Patients: "Have You No Shame?"
}

This article was published in the following Dove Press journal: Journal of Pain Research

\author{
Michael E Schatman $\mathbb{D}^{1,2}$ \\ Hannah Shapiro ${ }^{3}$ \\ Jeffrey Fudin (iD ${ }^{4-7}$ \\ 'Department of Diagnostic Sciences, \\ Tufts University School of Dental \\ Medicine, Boston, MA, USA; \\ ${ }^{2}$ Department of Public Health and \\ Community Medicine, Tufts University \\ School of Medicine, Boston, MA, USA; \\ ${ }^{3}$ McLean Hospital, Division of Alcohol, \\ Drugs, and Addiction, Harvard Medical \\ School, Boston, MA, USA; ${ }^{4}$ Remitigate \\ Therapeutics, Delmar, NY, USA; \\ ${ }^{5}$ Department of Pharmacy Practice, \\ Albany College of Pharmacy, Albany, NY, \\ USA; 'Department of Pharmacy Practice, \\ Western New England University, \\ Springfield, MA, USA; ${ }^{7}$ Stratton VA \\ Medical Center, Albany, NY, USA
}

The Affordable Care Act (ACA) was signed into law in March of 2010 by President Barack Obama, and represented the most significant expansion of health care coverage and regulatory overhaul since the establishment of Medicare and Medicaid in $1965 .{ }^{1}$ The expansion of the number of individuals covered by health insurance under the ACA, most notably the clause prohibiting insurers from refusing to cover those with pre-existing conditions, has dramatically improved access to chronic pain management for approximately 50 million Americans living with chronic pain. ${ }^{2}$ For a number of years, we have been writing about the urgent need to improve the deteriorating quality of pain management in the United States. ${ }^{3-6}$ Many patients believe that the war on prescription opioids, patients who rely upon them, and physicians with the audacity to still prescribe them has resulted in the marginalization of the nation's pain care system. ${ }^{7-11}$ However, the looming potential demise of the ACA based purely on political motivations and characterological flaws presents an existential threat of colossal proportions to chronic pain patients.

The expansion of those covered by health care insurance as a direct result of the ACA has been much heralded. By 2016, the number of Americans who were without insurance was reduced by almost $50 \% .{ }^{12}$ Unfortunately, since entering office, the current presidential administration has ostensibly been on a mission to dismantle the ACA, with particular vendettas against its open enrollment policies and improved access and maintenance of Medicaid coverage. ${ }^{13}$ As a result, the number of uninsured American adults has increased gradually since the beginning of the Trump presidency, although is still considerably lower than was the case prior to the enactment of the ACA. ${ }^{14,15}$ Due to the economic crisis secondary to the COVID-19 pandemic, the uninsured population in the United States is expected to rise by almost 3 million by the end of $2020 .{ }^{16}$ Unfortunately, this increase is likely to represent only the tip of the iceberg if the ACA is to be dismantled.

The current administration's approaches to striking down the ACA have been multifaceted, and, in some cases, nefarious. In a recent article from the Brookings Institution, the author described the six ways in which the president has attempted to sabotage the act, ${ }^{17}$ with the first five pertaining to strategies aimed at reducing enrollment. Based on the data presented above, this scheme has been at least somewhat successful. The sixth strategy that the author lists, persuading the
Correspondence: Michael E Schatman Tel +I (425) 647-4880

Email Michael.Schatman@tufts.edu 
Supreme Court to strike down the ACA as "unconstitutional," did not appear to be realistic - prior to the untimely death of Associate Justice Ruth Bader Ginsburg and the subsequent nomination and confirmation of the extremely conservative and self-professed textualist Associate Justice Amy Coney Barrett to fill her seat. Given Barrett's history of sharp criticism of the ACA's constitutionality, many Americans rightly fear that the act may soon be overturned. The Supreme Court is scheduled to hear oral argument for California et al v. Texas et al. on November 10th. Potential outcomes of California et al v. Texas et al include removal of the individual mandate or striking down the entire ACA as unconstitutional. ${ }^{18}$

Based on a 2017 analysis by the US Department of Health and Human Services (HHS), as many as 133 million Americans suffer from a pre-existing condition, ${ }^{19}$ coverage for which is guaranteed by the ACA. This figure is consistent with a 2019 study that found that prior to the ACA, roughly $50 \%$ of patients reported at least one pre-existing condition, while postACA, approximately $70 \%$ of patients reported at least one pre-existing condition. ${ }^{20}$ These findings are also consistent with a more recent Gallup Poll, in which $43 \%$ of households reported pre-existing conditions. ${ }^{21}$ Should the ACA be overturned, insurance companies (not-for-profit as well as for-profit) will have the option of suspending coverage for any condition that they deem to be pre-existing, be that diabetes, mental health disorders, HIV/AIDS, cancer, pregnancy, heart disease, chronic pain, or numerous other conditions. HHS noted, "Any of these 133 million Americans could have been denied coverage, or offered coverage only at an exorbitant price, had they needed individual market health insurance before 2014."

Much has been written about the failure of health insurance companies to serve as fiduciaries to those they cover, as they are concerned solely with their bottom lines rather than with enrollee well-being. ${ }^{22-26}$ This is particularly true of for-profit insurers In fact, McFall has noted that limiting profitability of insurers was actually a goal of the $\mathrm{ACA}^{27}$ Not surprisingly, however, health insurance profit margins tripled between 2016 and 2018 as regulations were rolled back. ${ }^{28}$

With 50 million chronic pain patients in the United States, ${ }^{2}$ many, and likely most, would lose any access to pain care should ACA be overturned, as chronic pain would clearly represent a pre-existing condition. Surprisingly, in their 2017 policy brief, ${ }^{19}$ HHS did not include chronic pain in its list of common pre-existing conditions. Chronic pain and its comorbidities are expensive to treat indiscriminately, and even more expensive to treat well. Most of these conditions are ideally treated from an interdisciplinary model, although such treatment has essentially been unavailable in the United States private sector for many years due to insurers' refusal to cover this effective yet labor-intensive approach. ${ }^{23,29-31}$

Systematic reviews have identified positive associations between chronic pain and a number of psychologi$\mathrm{cal} /$ psychiatric conditions, including general anxiety disorder, ${ }^{32}$ post-traumatic stress disorder, ${ }^{33}$ depression, ${ }^{34}$ suicidality, ${ }^{35}$ sleep disturbance, ${ }^{36}$ and neurocognitive deficits. ${ }^{37}$ Systematic reviews have also identified positive relationships between chronic pain and numerous physical conditions, including respiratory disorders, ${ }^{38}$ diabetes, ${ }^{39}$ obesity, ${ }^{40}$ heart rate variability (a predictor of cardiovascular morbidity and mortality), ${ }^{41}$ and cardiovascular and cerebrovascular disease. ${ }^{42}$ Could insurers potentially disallow coverage for treatment of these numerous comorbidities simply based upon their empirically established relationships to chronic pain? This might represent a stretch, although given the health insurance industry's current levels of anxiety regarding a single-payer option resulting in an erosion of their profits, it certainly cannot be ruled out as a possibility. For example, self-medication of pain with alcohol is extremely common. ${ }^{43-46}$ If a selfmedicating chronic pain patient were to consequently develop an Alcohol Use Disorder requiring potentially expensive rehabilitative treatment, would it not be feasible for an insurer to refuse to cover its costs by attributing to it the status of a comorbidity of a pre-existing condition?

For a number of years, the ACA was unpopular among the majority of Americans, largely due to conservative propaganda. ${ }^{47}$ Although the ACA has been much-maligned primarily for political purposes, research demonstrates that it reduces out-of-pocket expenses for health care dramaticallyparticularly for lower-income individuals. ${ }^{48}$ Consequent to this research coupled with a divisive lack of trust for the current administration, ${ }^{49}$ a recent Kaiser Family Foundation poll predictably indicated that a clear majority of Americans are now in favor of the ACA. ${ }^{50}$ Perhaps more significant is the poll's finding that $72 \%$ believe that it is "very important" to guard against the prohibition of the ACA's clause that prevents health insurers from denying coverage for people with pre-existing conditions. Yet, the current presidential administration and the increasingly more conservative 
Supreme Court are likely to "soldier on", irrespective of the will of the American people.

In summary, all Americans will be adversely affected should the ACA be repealed. Those who are most vulnerable are likely to be punished most severely should the administration be successful in striking down a program that protects Americans' health and well-being, and the approximately 50 million American citizens with chronic pain are extremely vulnerable, ${ }^{51,52}$ to say the least. According to a 2018 article by Stein and Allcorn, President Trump's efforts to repeal the ACA do not represent sound public policy, but rather reflect his narcissistic and racially-driven hatred of President Barack Obama. $^{53}$ Paradoxically, a 2019 Kaiser Family Foundation poll found that although $79 \%$ of selfidentified Republicans supported overturning the ACA, that figure decreased to only $45 \%$ if the repeal would potentially result in loss of coverage for pre-existing conditions. $^{54}$ Although the president has made "promises" that pre-existing conditions protection will continue under his "new health plan", his failure to present such a plan to date has many doubting the veracity of this claim. ${ }^{55}$ As health care providers who have dedicated our careers to advocating for vulnerable chronic pain patients, we have little recourse at this juncture, other than to simply question, "President Trump - have you no shame?"

\section{Disclosure}

Dr Michael E Schatman is a research consultant for Modoscript and Firstox, outside the submitted work. Dr Jeffrey Fudin reports non-financial support as a consultant and/or speakers bureau for AcelRx Pharmaceuticals, GlaxoSmithKline (GSK), BioDelivery Sciences International, Firstox Laboratories, Rockpointe, Inc, Scilex Pharmaceuticals, Salix Pharmaceuticals, and Abbott Laboratories, outside the submitted work. The authors report no other conflicts of interest in this work.

\section{References}

1. Frean M, Gruber J, Sommers BD. Premium subsidies, the mandate, and medicaid expansion: coverage effects of the Affordable Care Act. $J$ Health Econ. 2017;53:72-86. doi:10.1016/j.jhealeco.2017.02.004

2. Dahlhamer J, Lucas J, Zelaya C, et al. Prevalence of chronic pain and high-impact chronic pain among adults - United States, 2016. MMWR Morb Mortal Wkly Rep. 2018;67(36):1001-1006. doi:10.15585/mmwr. mm6736a2

3. Atkinson TJ, Schatman ME, Fudin J. The damage done by the war on opioids: the pendulum has swung too far. J Pain Res. 2014;7:265-268.
4. Fudin J, Pratt Cleary J, Schatman ME. The MEDD myth: the impact of pseudoscience on pain research and prescribing-guideline development. J Pain Res. 2016;9:153-156.

5. Schatman ME, Shapiro H. Damaging state legislation regarding opioids: the need to scrutinize sources of inaccurate information provided to lawmakers. J Pain Res. 2019;12:3049-3053. doi:10.2147/JPR.S235366

6. Schatman ME, Wegrzyn EL. The United States Drug Administration and prescription opioid production quotas: an end game of eradication? J Pain Res. 2020;13:2629-2631. doi:10.2147/JPR. S285835

7. Carvalho AS, Pereira SM, Jácomo A, et al. Ethical decision-making in pain management: a conceptual framework. $J$ Pain Res. 2018;11:967-976. doi:10.2147/JPR.S162926

8. Becker-Leckrone M. The stories we tell about opioids. Narrat Inq Bioeth. 2018;8(3):193-196.

9. Rose ME. Are prescription opioids driving the opioid crisis? Assumptions vs facts. Pain Med. 2018;19(4):793-807. doi:10.1093/ $\mathrm{pm} / \mathrm{pnx} 048$

10. Schottenfeld JR, Waldman SA, Gluck AR, Tobin DG. Pain and addiction in specialty and primary care: the bookends of a crisis. J Law Med Ethics. 2018;46(2):220-237. doi:10.1177/10731105187 82923

11. Ritchie CS, Garrett SB, Thompson N, Miaskowski C, Bowers BJ. Unintended consequences of opioid regulations in older adults with multiple chronic conditions. Gerontologist. 2020;60(7):1343-1352. doi:10.1093/geront/gnaa016

12. Uberoi N, Finegold K, Gee E Health insurance coverage and the Affordable Care Act, 2010-2016; 2016. Available from: https://aspe. hhs.gov/system/files/pdf/187551/ACA2010-2016.pdf. Accessed October 15, 2020.

13. Haeder SF, Yackee SW. A look under the hood: regulatory policy making and the Affordable Care Act. J Health Polit Policy Law. 2020;45(5):771-786. doi:10.1215/03616878-8543250

14. Witters D. U.S. Uninsured rate rises to four-year high; 2019. Available from: https://news.gallup.com/poll/246134/uninsured-raterises-four-year-high.aspx. Accessed October 15, 2020.

15. Garfield R, Tolbert J Health insurance coverage in the United States, 2010-2019; 2020. Available from: https://www.kff.org/policy-watch /what-we-do-and-dont-know-about-recent-trends-in-health-insurancecoverage-in-the-us/. Accessed October 15, 2020.

16. LaPointe $\mathrm{J}$ Estimate shows uninsured population rising by $2.9 \mathrm{M}$ by end of 2020; 2020. Available from: https://revcycleintelligence.com/ news/estimate-shows-uninsured-population-rising-by-2.9m-by-end-of -2020. Accessed October 15, 2020.

17. Thompson FJ Six ways Trump has sabotaged the Affordable Care Act; 2020. Available from: https://www.brookings.edu/blog/fixgov/ 2020/10/09/six-ways-trump-has-sabotaged-the-affordable-care-act/. Accessed October 16, 2020.

18. California, et al v. Texas, et al. 945 F.3d 355 (5th Cir. 2019), cert. granted (19-840), _ U.S. __ (2020).

19. United States Department of Health and Human Services. Health insurance coverage for Americans with pre-existing conditions: the impact of the Affordable Care Act. ASPE issue brief; 2017. Available from: https://aspe.hhs.gov/system/files/pdf/255396/PreExistingConditions.pdf. Accessed October 16, 2020.

20. Huguet N, Angier H, Hoopes MJ, et al. Prevalence of pre-existing conditions among community health center patients before and after the Affordable Care Act. J Am Board Fam Med. 2019;32(6):883-889. doi:10.3122/jabfm.2019.06.190087

21. McCarthy J 43\% of U.S. households report preexisting conditions; 2019. Available from: https://news.gallup.com/poll/269003/house holds-report-preexisting-conditions.aspx. Accessed October 21, 2020.

22. Richmond DR. Trust me: insurers are not fiduciaries to their insured. Kentucky Law J. 1999-2000;881:1-32. 
23. Schatman ME. The role of the health insurance industry in perpetuating suboptimal pain management: ethical implications. Pain Med. 2011;12:415-426. doi:10.1111/j.1526-4637.2011.01061.x

24. Schatman ME, Webster LR. The health insurance industry: perpetuating the opioid crisis through policies of cost-containment and profitability. J Pain Res. 2015;8:153-158. doi:10.2147/JPR.S83368

25. Richmond J, Powell W, Maurer M, et al. Public mistrust of the U.S. health care system's profit motives: mixed-methods results from a randomized controlled trial. J Gen Intern Med. 2017;32 (12):1396-1402. doi:10.1007/s11606-017-4172-1

26. Rosenthal E. An American Sickness: How Healthcare Became Big Business and How You Can Take It Back. New York: Penguin Press; 2017.

27. McFall L. Personalizing solidarity? The role of self-tracking in health insurance pricing. Econ Soc. 2019;48(1):52-76. doi:10.1080/ 03085147.2019.1570707

28. National Association of Insurance Commissioners. U.S. Health Insurance Industry; 2018. Available from: https://naic.org/docu ments/topic_insurance_industry_snapshots_2018_health_ins_ind_ report.pdf. Accessed October 16, 2020.

29. Schatman ME. The demise of the multidisciplinary chronic pain management clinic: bioethical perspectives on providing optimal treatment when ethical principles collide. In: Schatman ME, editor. Ethical Issues in Chronic Pain Management. New York: Informa Healthcare; 2007:43-62.

30. Schatman ME. Interdisciplinary chronic pain management: perspectives on history, current status, and future viability. In: Ballantyne JC, Rathmell JP, Fishman SM, editors. Bonica's Management of Pain. 4th ed. Philadelphia: Lippincott, Williams \& Wilkins; 2010:1523-1532.

31. Schatman ME. Interdisciplinary chronic pain management: international perspectives. Pain. 2012;20(7):1-5.

32. Haller H, Cramer H, Lauche R, Gass F, Dobos GJ. The prevalence and burden of subthreshold generalized anxiety disorder: a systematic review. BMC Psychiatr. 2014;14:128. doi:10.1186/1471-244X-14-128

33. Fishbain DA, Pulikal A, Lewis JE, Gao J. Chronic pain types differ in their reported prevalence of post -traumatic stress disorder (PTSD) and there is consistent evidence that chronic pain is associated with PTSD: an evidence-based structured systematic review. Pain Med. 2017;18(4):711-735.

34. IsHak WW, Wen RY, Naghdechi L, et al. Pain and depression: a systematic review. Harv Rev Psychiatry. 2018;26(6):352-363. doi:10.1097/HRP.0000000000000198

35. Spiegel B, Schoenfeld P, Naliboff B. Systematic review: the prevalence of suicidal behaviour in patients with chronic abdominal pain and irritable bowel syndrome. Aliment Pharmacol Ther. 2007;26 (2):183-193. doi:10.1111/j.1365-2036.2007.03357.x

36. Kelly GA, Blake C, Power CK, O'Keeffe D, Fullen BM. The association between chronic low back pain and sleep: a systematic review. Clin J Pain. 2011;27(2):169-181. doi:10.1097/AJP.0b013e3181f3bdd5

37. Higgins DM, Martin AM, Baker DG, Vasterling JJ, Risbrough V. The relationship between chronic pain and neurocognitive function: a systematic review. Clin J Pain. 2018;34(3):262-275. doi:10.1097/ AJP.0000000000000536

38. Beeckmans N, Vermeersch A, Lysens R, et al. The presence of respiratory disorders in individuals with low back pain: a systematic review. Man Ther. 2016;26:77-86. doi:10.1016/j. math.2016.07.011

39. Mijnhout GS, Kollen BJ, Alkhalaf A, Kleefstra N, Bilo HJ. Alpha lipoic acid for symptomatic peripheral neuropathy in patients with diabetes: a meta-analysis of randomized controlled trials. Int $J$ Endocrinol. 2012;2012:456279. doi:10.1155/2012/456279

40. Narouze S, Souzdalnitski D. Obesity and chronic pain: systematic review of prevalence and implications for pain practice. Reg Anesth Pain Med. 2015;40(2):91-111. doi:10.1097/AAP.0000000000000218
41. Meeus M, Goubert D, De Backer F, et al. Heart rate variability in patients with fibromyalgia and patients with chronic fatigue syndrome: a systematic review. Semin Arthritis Rheum. 2013;43 (2):279-287. doi:10.1016/j.semarthrit.2013.03.004

42. Fayaz A, Ayis S, Panesar SS, Langford RM, Donaldson LJ. Assessing the relationship between chronic pain and cardiovascular disease: a systematic review and meta-analysis. Scand J Pain. 2016;13:76-90. doi:10.1016/j.sjpain.2016.06.005

43. Goebel JR, Compton P, Zubkoff L, et al. Prescription sharing, alcohol use, and street drug use to manage pain among veterans. $J$ Pain Symptom Manage. 2011;41(5):848-858.

44. Alford DP, German JS, Samet JH, Cheng DM, Lloyd-Travaglini CA, Saitz R. Primary care patients with drug use report chronic pain and self-medicate with alcohol and other drugs. J Gen Intern Med. 2016;31(5):486-491. doi:10.1007/s11606-016-3586-5

45. Haighton C, Kidd J, O'Donnell A, Wilson G, McCabe K, Ling J. 'I take my tablets with the whiskey': a qualitative study of alcohol and medication use in mid to later life. PLoS One. 2018;13(10):e0205956. doi:10.1371/journal.pone.0205956

46. Reif S, Adams RS, Ritter GA, Larson MJ. Exploration of the association of selected pain diagnoses with risky alcohol use among active duty soldiers. Subst Abus. 2019;1-7. doi:10.1080/ 08897077.2019.1671944

47. Kingsley D. Quantification and scientism in political science: domination of discourse by experts presenting mathematical models of reality. Poverty Public Policy. 2018;10(2):198-221. doi:10.1002/ pop4.211

48. Liu C, Tsugawa Y, Weiser TG, Scott JW, Spain DA, MaggardGibbons M. Association of the US Affordable Care Act with out-ofpocket spending and catastrophic health expenditures among adult patients with traumatic injury. JAMA Netw Open. 2020;3(2):e200157. doi:10.1001/jamanetworkopen.2020.0157

49. Beer $\mathrm{T} 68 \%$ of Americans do not Trust what Trump says about coronavirus pandemic, survey says; 2020. Available from: https:// www.forbes.com/sites/tommybeer/2020/09/13/68-of-americans-donot-trust-what-trump-says-about-coronavirus-pandemic-survey-says /\#579f3e5a6486. Accessed October 22, 2020.

50. Hamel L, Kirzinger A, Muñana C, Lopes L, Kearney A, Brodie M 5 charts about public opinion on the Affordable Care Act and the Supreme Court; 2020. Available from: https://www.kff.org/healthreform/poll-finding/5-charts-about-public-opinion-on-the-affordablecare-act-and-the-supreme-court/. Accessed October 22, 2020.

51. Giordano J, Schatman ME. A crisis in chronic pain care: an ethical analysis; Part 2. Proposed structure and function of an ethics of pain medicine. Pain Physician. 2008;11:589-595.

52. Kertesz SG, Manhapra A, Gordon AJ. Nonconsensual dose reduction mandates are not justified clinically or ethically: an analysis. J Law Med Ethics. 2020;48(2):259-267. doi:10.1177/1073110520935337

53. Stein HF, Allcorn S. A fateful convergence: animosity toward Obamacare, hatred of Obama, the rise of Donald Trump, and overt racism in America. J Psychohist. 2018;45(4):234-243.

54. Altman D Trump may lose swing voters by asking SCOTUS to strike down the ACA; 2020. Available from: https://www.axios.com/trumpmay-lose-swing-voters-by-asking-scotus-to-strike-down-the-aca $-96 \mathrm{ef73dd}-4 \mathrm{f} 88-4 \mathrm{~b} 17-87 \mathrm{c} 4-\mathrm{cecd} 68 \mathrm{f} 76192 . \mathrm{html}$. Accessed October 26, 2020.

55. Yen H, Alonso-Zalvidar R, Boak J AP FACT CHECK: Trump's dubious claims on health care, court; 2020. Available from: https:// apnews.com/article/election-2020-race-and-ethnicity-ap-fact-checkvirus-outbreak-voting-fraud-and-irregularities-5dd4ed156b8b8f9c36c d1812ed1b317c. Accessed October 26, 2020. 


\section{Publish your work in this journal}

The Journal of Pain Research is an international, peer reviewed, open access, online journal that welcomes laboratory and clinical findings in the fields of pain research and the prevention and management of pain. Original research, reviews, symposium reports, hypothesis formation and commentaries are all considered for publication. The manuscript management system is completely online and includes a very quick and fair peer-review system, which is all easy to use. Visit http:// www.dovepress.com/testimonials.php to read real quotes from published authors.

Submit your manuscript here: https://www.dovepress.com/journal-of-pain-research-journal 